психологического объекта (существующего для нас в виде набора чисел) с помощью известных статистических процедур, либо мы изучаем свойства самих чисел, которые могут быть и не связанными со свойствами психологического объекта (явления). В руководствах по экспериментальной психологии описана формализованная процедура перехода от области психологических объектов к области чисел с помощью психометрических шкал, созданной в свое время С. Стивенсом. Но там ничего не сказано о формализованной процедуре обратного перехода от области чисел к области психологических объектов. Эту процедуру еще следует разрабатывать.

Таким образом, по мере развития экспериментальной психологии начинают проступать такие проблемы, существование которых еще некоторое время назад невозможно было и допускать. Если психологи хотят повысить точность своих экспериментальных процедур, то эти проблемы надо решать уже сейчас.

\title{
ИЗУЧЕНИЕ ЭМОЦИОНАЛЬНЫХ АСПЕКТОВ ВОЛЕВОЙ РЕГУЛЯЦИИ
}

\section{Белякова Д.Н.} Научный руководитель: д.псх.н., профессор Мельников В.М.

В настоящее время многие исследователи (О.А. Конопкин, В.И. Чирков, В.А. Иванников) проявляют большой интерес к изучению эмоциональных аспектов волевой регуляции. Такой интерес имеет глубокие корни и во все времена изучался многими психологами.

Согласно теории дифференциальных эмоций психолога Изард К.Э., интерес является доминирующим мотивационным состоянием в повседневной деятельности нормального человека. Зачастую эмоция интереса выступает в комбинации, а иногда в конфликте с одной или несколькими другими эмоциями, и при этом постоянно взаимодействует с перцептивнокогнитивными процессами. Интеракции «интерес - когнитивный процесс» обусловлены аффективно-когнитивными ориентациями, или структурами, характеризующими конструктивную, творческую деятельность здорового индивида. Если все жизненные потребности человека удовлетворены, и он не испытывает отрицательных эмоций, то он способен действовать в соответствии с позитивным мотивационным побуждением, исходящим от аффективнокогнитивных структур, аффективная часть которых представлена эмоцией интереса-возбуждения. Другая положительная эмоция - радость - играет в данном случае второстепенную роль, она поддерживает конструктивное, творческое поведение[1].

Цель исследования - изучение эмоций, которые включены в процесс эмоционально-волевой регуляции.

Объект исследования - эмоция интереса

Предмет исследования - эмоции, возникающие при волевом усилии

Гипотеза исследования - при волевом усилии эмоция интереса является наиболее выраженной. 
Задачи исследования:

1.Изучить особенности эмоциональных состояний эмоционально-волевой регуляции.

2. Выявить наиболее характерные эмоциональные составляющие.

3. Отследить связь эмоций и воли.

Изучая работы психологов очевидно, что любая эмоция выполняет мотивационные функции.

Сформулированное Адлером (Adler, 1964) понятие «социального интереса», или «социального чувства», можно рассматривать как один из видов когнитивной ориентации, характеризующейся интересом к людям и к их благополучию. Адлер пишет: «Земля, на которой мы живем, заставляет человека трудиться и создает необходимость в разделении труда. Социальное чувство выражается в совместном труде ради общего блага. Для социально мыслящего человека очевидно, что каждый должен получать вознаграждение за свои труд, что эксплуатация чужого труда не может способствовать благу человечества» [2].

Адлер утверждал, что только люди с развитым социальным чувством вправе решать проблемы, встающие перед человечеством.

Эмоции, по А. Н. Леонтьеву, - состояния, проявляющиеся во внешнем поведении. Они носят отчетливо выраженный ситуационный характер, т.е. выражают оценочное личностное отношение к складывающимся или возможным ситуациям, к своей деятельности и своим проявлениям в них. Они также носят идеаторный характер - т.е. способны предвосхищать ситуации и события, которые реально еще не наступили, и возникают в связи с представлениями о пережитых или воображаемых ситуациях [4].

Для проверки гипотезы провели следующее экспериментальное исследование: Выборка исследования составляет 30 человек -мужчины и женщины (не спортсмены). Все испытуемые исследовались с помощью одной и той же процедуры. В качестве единицы анализа был взят волевой эпизод. В одно и то же время, в одном месте проводился забег протяженностью пять километров. После преодоления (или не преодоления) дистанции испытуемым предлагалось заполнить анкеты, в которых необходимо было указать какие эмоции переживал испытуемый и какова была их динамика в процессе преодоления дистанции. Всего девять эмоций: интерес, радость, удивление, горе, гнев, отвращение, страх, стыд, вина. Мы предполагаем, что волевой эпизод покажет процесс эмоционально-волевой регуляции, который состоит из постоянно меняющихся эмоций и мыслей. Данный волевой эпизод имеет объективные параметры - время, результат, эффективность. А также субъективные характеристики - усилие, внутреннее напряжение, чувство преодоления трудностей. В зависимости от того как данный волевой эпизод воспринимается испытуемыми можно проследить установки, цели и установки испытуемых, их проблемы и установки. 
Таблица 1- средние значения переживаемых эмоций испытуемыми в процессе преодоления дистанции (волевого эпизода).

\begin{tabular}{|l|l|}
\hline \multicolumn{1}{|c|}{ эмоции } & \multicolumn{1}{c|}{ среднее значение } \\
\hline интерес & 9,533333 \\
\hline радость & 8,966667 \\
\hline удивление & 6,766667 \\
\hline горе & 2,666667 \\
\hline гнев & 3,866667 \\
\hline отвращение & 2,473333 \\
\hline презрение & 2,333333 \\
\hline страх & 2,333333 \\
\hline стыд & 4,333333 \\
\hline
\end{tabular}

Из таблицы 1 видно, что среднее значение эмоции «интерес» является самым большим. На втором месте - эмоция «радость». Помимо предлагаемого теста, испытуемые сразу же после преодоления дистанции делились своими впечатлениями устно и письменно в форме не больших «живых» рассказов, что позволило получить более достоверные данные. Интересным фактом является то, что эмоцию стыд переживали испытуемые, которые не смогли преодолеть дистанцию до конца.

Ещё одним важным моментом является то, что длину дистанции (то есть продолжительность усилий) не знал ни один из 30 испытуемых. И так как в исследовании принимали участие люди, которые не натренированы в беге, то дистанция в два раза меньше предложенной также была очень тяжелым испытанием и, без спорно, вызвала бурю эмоций при выполнении волевого эпизода. Многие испытуемые не смогли преодолеть данную дистанцию, и даже те кто преодолел забег высказывались о том, что если бы знали о длине дистанции, то наверняка отказались от проведения исследования.

Основной эмоцией, сопровождающей волевое усилие является интерес. Как писал Изард К.Э.: «Рассматривая характеристики эмоции интереса: «Интерес - позитивная эмоция, она переживается человеком чаще, чем прочие эмоции. Интерес играет исключительно важную мотивационную роль в формировании и развитии навыков, умений и интеллекта. Интерес единственная мотивация, которая обеспечивает работоспособность человека. Кроме того, он насущно необходим для творчества. Интерес - нечто иное и нечто большее, чем внимание» [1]. Любимая игрушка или игра порой настолько увлекают ребенка, что он не чувствует голода или усталости. Не только дети забывают о голоде и усталости, когда испытывают эмоцию интересавозбуждения. Мы тоже порой бываем так захвачены работой, что не чувствуем голода и пропускаем обеденный перерыв. Возбуждение может притупить даже боль. Нередки случаи, когда спортсмен, получив во время игры травму, начинал ощущать боль только по окончании матча. Известно также, что альпинисты забывают о всех физиологических потребностях (драйвах), когда от вершины их отделяет несколько метров. 
Путешественники терпят лишения неделями, месяцами и даже годами настолько сильны в них жажда открытия, стремление к заветной цели[1].

Эмоция интереса, являясь мотивирующей силой постоянного сенсорного взаимодействия человека с окружающей средой, способствует развитию его мозга. Она играет большую роль в формировании и развитии определенного навыка.

\section{Литература}

1. Изард К.Э. Психология эмоций / Перев. с англ. - СПб: Издательство «Питер», 1999. - 464 с.: ил. (Серия «Мастера психологии»).

2. Адлер А. Практика и теория индивидуальной психологии. М., 1995.

3. Набиуллина Р.Р., Тухтарова И.В. Механизмы психологической защиты и совлодания со стрессом //Учебно-методическое пособие - Казань, 2003г. - 98 стр.

4. Леонтьев А.Н. Философия психологии: из научного наследия. М.: Издво Моск. ун-та, 1994.

5. Леонтьев Д.А. Общее представление о мотивации // Психология в вузе, 2004, № 1. С.

\section{СПЕЦИФИКА ПРЕДСТАВЛЕНИЙ ЖИТЕЛЕЙ ГОРОДА СОЧИ О ВОЛОНТЕРСКОЙ ДЕЯТЕЛЬНОСТИ}

Васькина А.A.

$\mathrm{XX}$ век - главная веха в развитии волонтерского движения. В современном мире волонтерская деятельность является прогрессивной формой объединения граждан, значимым ресурсом развития общества, посредством которого «воплощаются в жизнь замыслы человечества к достижению мира, свободы, безопасности, устанавливаются связи, которые независимо от различий способствуют тому, чтобы жить в здоровых, устойчивых сообществах, работать над решениями общих проблем народов» [1].

Истоки возникновения этого социально-культурного феномена в нашей стране кроются ещё в постсоветской России, однако периодом правового оформления института добровольчества в РФ стоит считать 2006 год, когда Правительством РФ была разработана и утверждена стратегия государственной молодежной политики до 2016 года, приоритетными направлениями которой были названы: содействие развитию и поддержке волонтерской деятельности; системное вовлечение молодежи в общественную жизнь; выявление, продвижение, поддержка активности молодежи и ее достижений в социальноэкономической, общественно-политической, творческой и спортивной сферах, что даст возможность молодым людям проявить себя, реализовать свой потенциал и получить заслуженное признание в России; организация добровольческого труда в России [2].

По данным британского благотворительного фонда CAF, в 2012 году Россия вошла первую десятку стран мира по числу волонтеров (21 млн. участников) [3]. На сегодняшний день, количество волонтеров в нашей стране значительно выросло и связано это, прежде всего, с последним событием, 